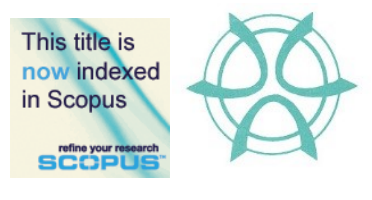

PLANNING MALAYSIA:

Journal of the Malaysian Institute of Planners

VOLUME 18 ISSUE 3 (2020), Page $104-117$

\title{
EVOLUTION OF WATERFRONT DEVELOPMENT IN LUMUT CITY, PERAK, MALAYSIA
}

\author{
Mohd Ismail Isa ${ }^{1}$ \\ School of Housing, Building and Planning, \\ UNIVERSITI SAINS MALAYSIA
}

\begin{abstract}
This study on the evolution of waterfront development in Lumut through physical improvement serves as one component in the formation of a city from the economic, social and environmental aspects. The current study aims to review the elements of urban design that offer an alternative to the revitalisation of the waterfront city in Lumut, Malaysia, particularly to upgrade the physical environment quality and economic vibrancy of cities. The objectives of this study are as follows: (1) examine the consideration and perceptions of urban design aspects given by the respondents related to the evolution of a Lumut waterfront city, and (2) identify urban design elements that have evidence of significant contributions to the revitalisation of the aforementioned city. This research comprises two components. The first component explains the analysis based on observation and the obtained secondary information. The second component is the inventory study and analysis related to the city design in the study area. The theoretical study involves city image enhancement concepts, basic methods and principles in improving the structure of city elements. It also elaborates that any improvement or modification that should be done in any of the city elements must proceed through a proper channel and adhere to improvement or modification steps that have been proposed by design experts. The reason is to create harmony between the city elements with their surroundings to form an image that has identity, structure and meaning. With effective consideration, the proposed development must be closely assessed for its use and function before any project is endorsed and enforced. Issues discovered by this study will facilitate the formulation of strategies and suitable proposals, and automatically ensures improvement of the economic, social and environmental conditions.
\end{abstract}

Keywords: Urban design, Urban waterfront revitalisation, Planning, Lumut.

${ }^{1}$ Lecturer at University Sains Malaysia Email: mohdismail.isa@usm.my 
PLANNING MALAYSIA

Journal of the Malaysia Institute of Planners (2020)

\section{INTRODUCTION}

One of the elements dominant in the conservation areas (urban conservation) is the notion of 'revitalisation'. Revitalisation is an effort to revive an area or town that has previously lived for a time (vital), but eventually gone into regression. One of the revitalisation elements was through visualisation and through reconstruction of the image of cities. Revitalisation is not something that is oriented on physical beauty alone but must be complemented with an economic improvement of society and cultural identity. The revitalisation approach must be able to identify and harness the potential of environmental resources, such as history, meaning and uniqueness of location and image of the place. This approach is not merely a physical improvement or had tapped portions of the city. Revitalisation is a continuous program from the early stages up to a long-term program, which involves the management of the area. The image generally refers to a picture or an idea, which serves as a resultant through observation by individuals or the public. The town image may constitute things that can be seen and heard, and which are appreciable or something that becomes the town's main activity or attraction. The image of a city can be produced through designing the city with proper town elements, such as by providing building, road, street furniture and landscaping. To form an image of a town, the structure and design for each town element, such as the building, road and landscape furniture, needs to be repaired from time to time to ensure that the town's image can be maintained continuously. In this case, the study of Lumut City in Perak focuses on the image enhancement study and the aspect of town elements used. The city has two places of attraction, namely, Lumut Jetty and Lumut Bus/Taxi Terminal. They appear to be the first destinations after one enters the city of Lumut. Lumut Jetty is the main entrance to Pangkor Island. Lumut Jetty is one of the accesses for visitors to cross the sea by boarding the ferries provided and paying a certain amount for the ticket price. The latest icon developed in the city of Lumut is the Lumut Waterfront. This area was developed as a tourist attraction, which provides facilities for the visitors. The Lumut Waterfront is divided into four elements, namely, Maritime Wing, Jetty Wing, Esplanade Wing and Marina Wing. Every element carries its concept, but the basis stands out as solely maritime-based. This development project was constructed to attract numerous tourists and improve the local economic scenario. Accordingly, the following questions should be answered. How does this situation affect city change through urban design elements? Will they continue to redevelop using attractions in the vicinity? What is the physical or visual impact if development continues? These questions are important and should be considered if a redevelopment project was undertaken. However, people will constantly approach it as long as the water element exists. This situation is sufficient to withstand waterfront development in the years ahead. 
Mohd Ismail Isa

Evolution of Waterfront Development in Lumut City, Perak, Malaysia

\section{REVIEW OF RELATED LITERATURE}

Dong (2004) indicated that the meaning of the waterfront development has various understandings. The aforementioned study emphasised that the content of waterfront development varies substantially, and concerns the characteristics of sites and cities. For example, urban waterfront development in Japan is one of the interrelated three water-related development concepts. The location is between waterside and coastal development. These development levels have come up in different fields. Waterfront development was evaluated as an urban planning field. Morena (2011) explained that 'the urban waterfront development was widely regarded as a frontier on contemporary urban development, attracting investment and publicity. Sydney, London, Amsterdam, Hong Kong, Tokyo, Toronto, Osaka, Kobe, and Dublin are examples of cities developed through the waterfront development process'. Yasin, Bond and McDonagh (2012) defined ideally as 'a development directly fronting on the water for any purposes and the water components can include river delta, coastal plains, wetlands, beaches and dunes, lagoons, and other water features. The boundary of where the water and land would meet is difficult to determine, and this boundary often differs by the laws and the administration of the countries. Waterfront development can include any combination of various land uses and waterfront projects can be new projects or redevelopments of existing waterfronts into new places. Some waterfront projects focused on industrial uses, such as industrial ports, whilst others focused on considerably recreational and tourism-oriented uses. A diversity of uses should occur along a waterfront, bringing in as many interests as possible to the waterfront. However, a diversity of uses does not need to occur within each project. Waterfronts are places to live, work and where we enjoy recreating. In recent years, managing water has become a major political and social topic because of climatic events that have caught plenty of media attention. People have been questioning whether waterfront properties should be promoted as a place to live, or whether giant walls should be built to protect people from advancing water levels anticipated by climate change experts. Wrenn, Casazza and Smart (1983) stated that waterfront development stimulated modern development in the cities. Therefore, the historical milestone of waterfront development should be understood (Yasin, Bond and McDonagh, 2010).

\section{RESEARCH METHODOLOGY}

This research comprises two components of the study, where each component of the study has its purpose of understanding and identifying the actual issues that may occur in the study area. The first component explains the analysis based on observation, together with the secondary information which has been obtained. The analysis seeks to explain the information gathered on the site ready to be analysed, to know the development potential for the study area. This section displays its concentration on a few major sectors, namely, the sectors of land use, 
city design, landscape and recreational sector, facilities and utilities, tourism and business sectors. For the image enhancement of a city, the element of redevelopment the city is worth considering, which leans on the existing development theme that has been decided by the Lumut-Seri Manjung District Local Planning. The image enhancement of cities with heritage elements must be sustained because the new surroundings created in the future will not tarnish the identity and uniqueness of this wonderful city of Lumut.

The second component is the inventory study and analysis related to the city design in the study area. The perception from the respondent should be able to determine the level of satisfaction and opinion of the respondents towards the city design element in the study area using a Likert scale. As a subset of the entire sample, as many as 100 respondents were selected to represent the researcher sample. They are chosen randomly without considering the status of their citizenship, whether they reside in Lumut. The researcher only requires the opinion and perception of Lumut waterfront from the perspective of city design. Questions would concentrate more on the components of the city design, such as infrastructural facilities, services offered, strength of place and visual and image of the surroundings. Through these basic components, the city element can be formed and progress would be created towards the city. Amongst the elements studied are old or new buildings, road furniture and landscape. These elements are analysed to show the significant improvement needed to enhance the image and productivity of Lumut waterfronts in particular. Automatically, it serves as a yardstick to the concept of revitalisation that needs to be done at Lumut waterfronts, regardless of whether the concept is fruitful or otherwise.

\section{ANALYSIS AND FINDINGS}

\section{i. First Component: Analysis of Survey (Urban Design Element)}

The perception questionnaire indicated that as much as $34 \%$ of the respondents who come to tour or vacation. The reason is that the Lumut Jetty serves as the only entrance to Pangkor Island. This situation was followed by the purpose of working in the place, which is represented by $22 \%$ because various types of development done by the Manjung City Council for the sake of improving the productivity and job opportunities of the residents have emerged. Meanwhile, the visitors that would arrive to sample the food there constitute $20 \%$. Plenty of food stalls have been provided on the basis of this observation. A total of $4 \%$ of visitors come for another purpose, which is for recreation. Refer to Figure 1(a) 

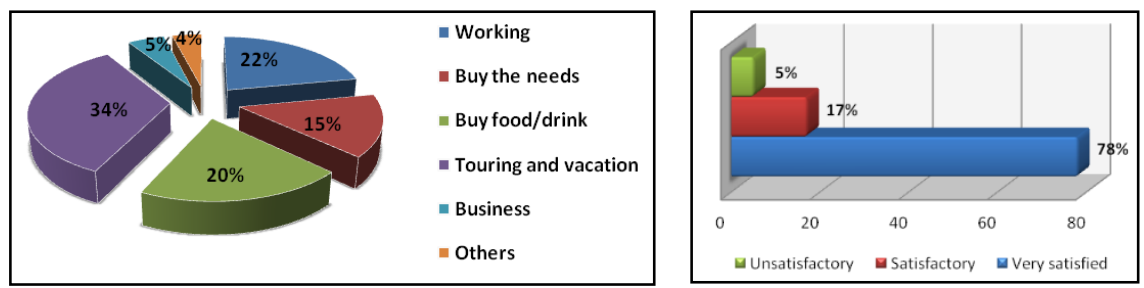

Figure 1: (a) The main purposes and activities of the visitors come to the area of study;

(b) The perceptions of the respondents towards the building design in the area of study.

Figure 1(b) shows the perception of the visitors towards the building design in the study area, in which $78 \%$ of the respondents have stated that the design in the area is satisfactory. The observation indicated that the buildings in this area have undergone some renovations for the sake of improving the image of Lumut City as a maritime city. A total of $17 \%$ stated that the design of the buildings in the area stays at a satisfactory level, and only 5\% stated otherwise. The reason is that the respondents have given the opinion that the Waterfront Lumut Stretch is the only place that has shown the maritime concept, whereas the element was not shown in other areas. The height of the building is also not uniform and has negatively affected the view. The landmark monument is important to highlight the image of a city. The questionnaire analysis indicated that $38 \%$ of the respondents have stated that the landmark in this area is satisfactory, and only $27 \%$ have informed that they are satisfied with the landmark monument in this area. Meanwhile, as much as $35 \%$ claimed that they are not happy with the landmark available in the area because they believe that the landmark should be erected at the entrance of Lumut City. Refer to Figure 2(a) Concerning Figure 2(b), which shows the perceptions of the respondents on the pedestrian space in the study area, $57 \%$ from the total number of respondents have stated that they are satisfied with the pedestrian space provided, whilst $38 \%$ of the respondents stated that they are simply satisfactory. Only $5 \%$ are in the opinion that the pedestrian space is unsatisfactory in this area. An interview with the Manjung City Council indicated that the MPM has taken a good step in repairing and maintaining the pedestrian space in this area. The maritime theme was frequently found in the pedestrian space to brighten up the surroundings. 

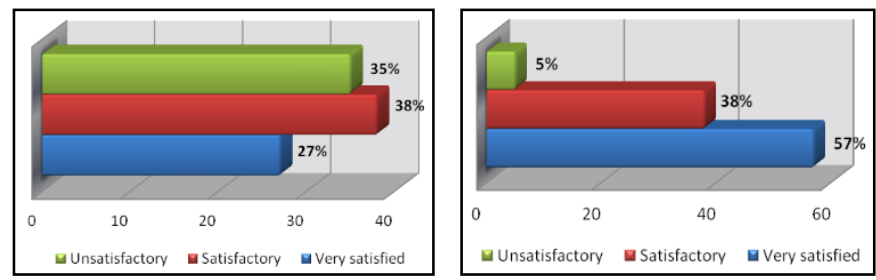

Figure 2: (a) Perception of respondents on the landmark in the study area; (b)

Percentage of the perception of respondents towards the pedestrian space in the area of study.

The rest area serves as an important asset for an area to attract the public to come for recreational purposes. Yielded from the questionnaire analysis of the respondents' perception of the public rest area in the study area, as much as $49 \%$ from the total number of respondents are satisfied with the public rest area available in the city. Refer to Figure 3(a). A total of 37\% stated that the public rest area was satisfactory. Evidently, the rest area for the public has been provided by the city council (MPM) for the visitors to rest and have some recreational activities. Meanwhile, the other $14 \%$ from the total number of respondents are dissatisfied with the facility of the rest area in the place because the public rest area provided lacks the proper shading and the provision of the place is an evidence of waste. Figure 3(b) shows that the respondents' perception of the landscape design in the study area. A total of $54 \%$ stated that they are extremely satisfied with the landscape design in this area. Thereafter, $43 \%$ stated that the landscape design in this area stays at a satisfactory level. In turn, only $3 \%$ determined that the landscape design was dissatisfactory. Consequently, the element of the landscape was prioritised in this area to brighten up the place with greeneries and to provide more shade to the visitors. Moreover, the arch/inflexible landscape element was also adopted to brighten up the place, other than being used as the seats provided for the visitors.
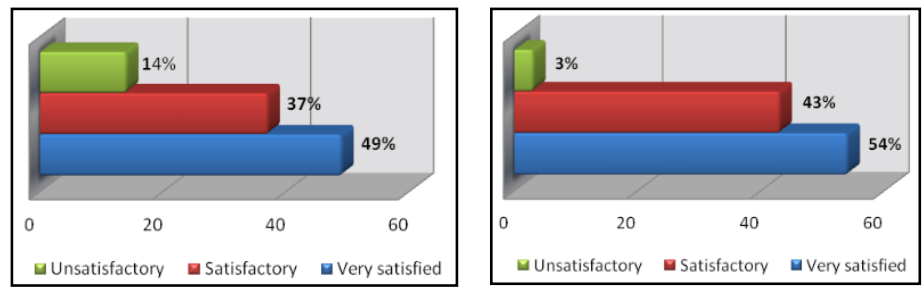

Figure 3: (a) Percentage of the perception of respondents towards the public rest area in the area of study; (b) Perception of respondents towards the landscape design in the area of study. 
Mohd Ismail Isa

Evolution of Waterfront Development in Lumut City, Perak, Malaysia

The outcome of the questionnaire analysis indicated that $53 \%$ stated that the conservation and preservation of old buildings are far from satisfactory. This situation is sequenced from the old buildings, mostly which were built in the 1940s that had not been given care properly. The study area does not have any building height control because the background of the sky amongst the buildings are not uniform. Meanwhile, as much as $32 \%$ agreed that it is satisfactory, whilst $15 \%$ stated that it is at a satisfactory level. Figure $4(a)$ shows that the attractive spot for the area in the district of Manjung is Lumut Jetty because it is the access to Pangkor Island. Figure 4(b) demonstrates the view of the respondents towards the city space and attractive spots in the study area. As high as $53 \%$ of the total number of respondents have stated that the city space and attractive spots in this area are at a satisfactory level. A total of $34 \%$ expressed that it is satisfactory. This was explained by the fact that there is plenty of development which emphasises the economic aspect of seeking to attract visitors. Thus, plenty of commercial centres have emerged for those who serve as tourist attractions when it comes to shopping. Only $8 \%$ stated that it falls short from being satisfactory and $5 \%$ have given another opinion that there has been excessive development implemented in this area, in which the effect of the development has been overlooked. Therefore, some flaws have been observed on the arrival of visitors to an area, even though the development investment has been costly.
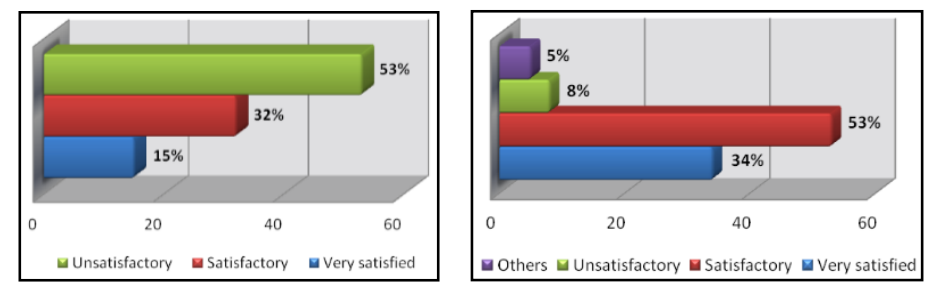

Figure 4: (a) Percentage of the perception of respondents towards the preservation and conservation of old buildings in the area of study; (b) Perception of respondents towards city area and attraction centres in the area of study.

Figure 5 shows the perception of respondents on the image of the study area. A total of $67 \%$ of the total number of respondents stated that the study area has a satisfactory image. Meanwhile, $24 \%$ stated that the image was satisfactory. Evidently, the maritime concept was instilled in the Lumut Waterfront Stretch in the development surrounding Lumut City. The concept automatically improves the image and attracts more tourists to come and visit. A systematically arranged planning and infrastructure would help to improve the image of this area. In turn, only $3 \%$ are unhappy with the image in the area. Meanwhile, the remaining $6 \%$ have a different perception. 
PLANNING MALAYSIA

Journal of the Malaysia Institute of Planners (2020)

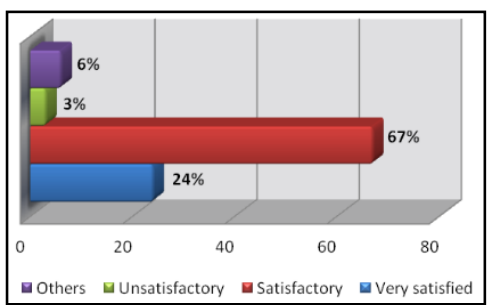

Figure 5: Perception of respondents towards the image in the area of study.

\section{ii. Second Component (Observation Analysis)}

The planning and development of the whole Lumut Waterfront project are divided into four main segments. The four main segments are the Maritime Wing, Jetty Wing, Esplanade Wing and Marina Wing. Every one of the segments was developed with various marina approaches and concepts, but were similar regarding the activities and designs to create a sequence. These areas accommodated various facilities and activities, whether for the tourists or the locals. Construction and detailing concentrate on the maritime concept, in which the approach of the living entities and sea environment are also human activities with the sea itself being introduced, with the adoption of modern architecture. The maritime concept has been included in four segments of the development and planning of Lumut Waterfront. This area progresses with a different approach and concept regarding the activity and design to create the sequence amongst all four areas. The 'Water-friendly' concept or water-based development is the main attraction and emphasised the development of Lumut Waterfront. Figure 6 shows all four areas, namely, Maritime Wing, Jetty Wing, Esplanade Wing and Marina Wing, and their functions to the City of Lumut. Given the maritime-based concept and development, it has altered the perspective and image of the City of Lumut. This situation automatically leaves an impact on the economic and social activities in this area.

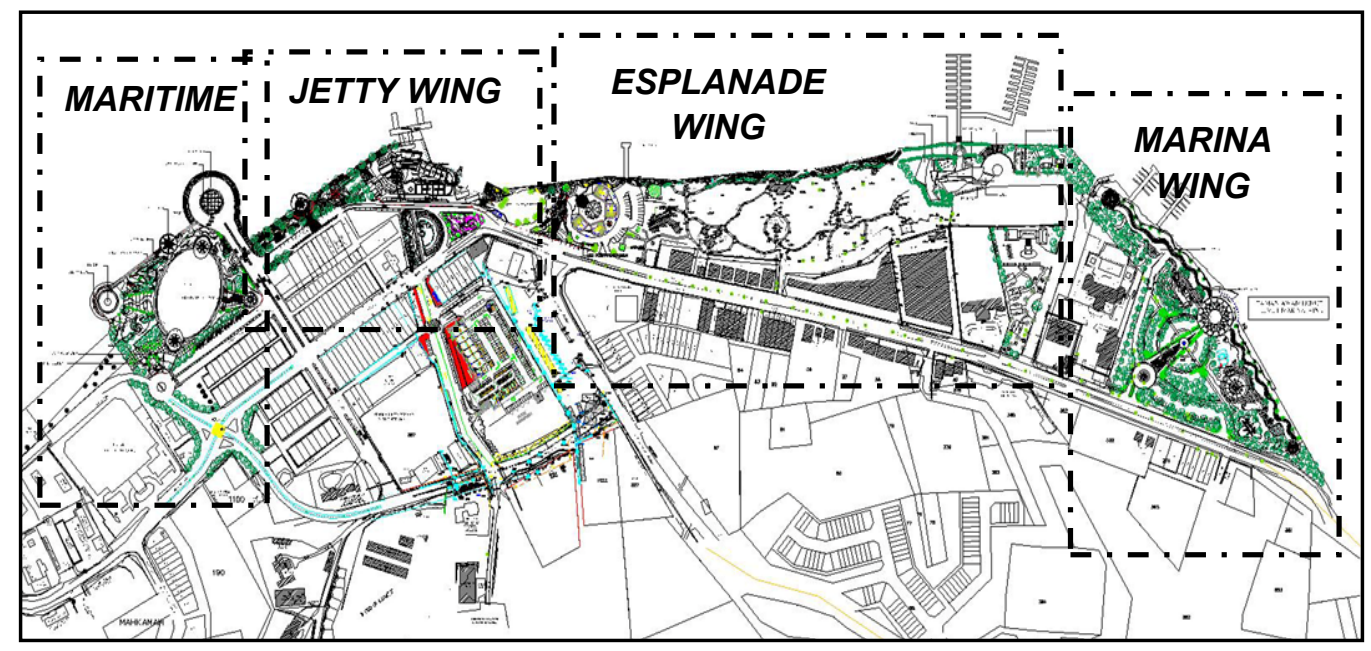


Mohd Ismail Isa

Evolution of Waterfront Development in Lumut City, Perak, Malaysia

Figure 6: Lumut Waterfront Stretch, The City of Lumut. Source: Adapted from City and Rural Planning Office, Manjung City Council (MPM)

\section{a. Maritime Wing}

Maritime Wing is an open area for the public for various recreational activities with their families. Public amenities, such as the mosque, public toilets, fishing platforms and other facilities, are provided. This area is suitable as a place for fairs or expos. Maritime Wing covers an area of 6.78 acres and the development cost has an expected worth of approximately RM40 million, where it covers a component of the Floating Circle Pathway that can be used as a performing stage. Moreover, the construction of the Maritime Plain, which can accommodate 40,000 people at one time. Such components as plazas and pedestrian facilities, kiosks and business spaces create additional job opportunities for residents. From the observations at the Maritime Wing, the buildings and facilities provided such functions as recreational places and places for them to have and enjoy their meals. This area is equipped with the shore restaurant, which emphasises the refreshing sea view, making this place crowded and cheerful at night. The peaceful and comfortable feelings towards the sea have further elevated the status of the place. Evidently, the design of the Maritime Wing, which is eco-friendly, has made it a location that is constantly frequented by the public. The inculcation of the ecofriendly concept into the building design has been a good and effective idea. In this positive integration, the function of the building associated with the surrounding design can improve the status of the building. The use of this space was more focused on public space and incorporates landscape features that may provide a balance between softscape and hardscape. (Refer to Picture 1)

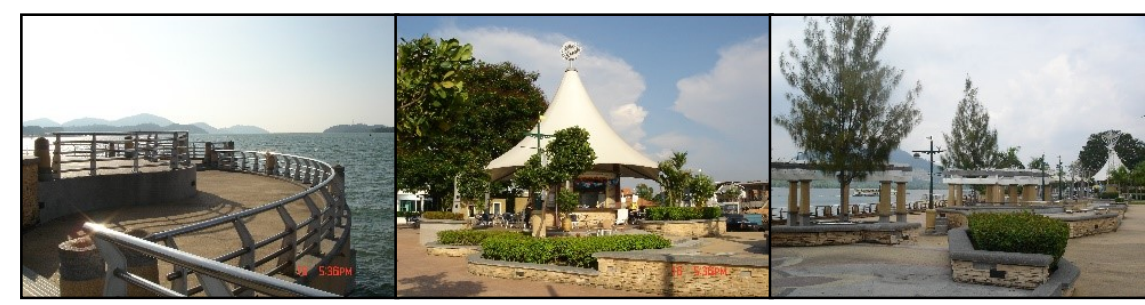

Picture 1: Maritime Wing

\section{b. 'Jetty Wing' Lumut Jetty}

Lumut Jetty covers an area of 3.8 acres and the development cost estimated was worth RM13 million, which includes the jetty plaza, equipped with various facilities, such as the restaurant, handicraft stalls, sea products, ticket counter, public toilet and operation offices. The Lumut Jetty Terminal (Jetty Wing) is a tourist's transit place to Pangkor Island (Refer to Picture 2(a)). This jetty is a great landmark to the city of Lumut. The design, which adopts the attributes of a 
marina, illustrated a new image that suits the theme. The construction materials used are concrete and glass, which highlighted the beauty of the architecture. The shading roof for the pedestrians was designed with the sea wave element, making the architectural work in the area unique and interesting. The provision of the Lumut Bazaar in front of the jetty makes it easy for visitors to do their shopping.
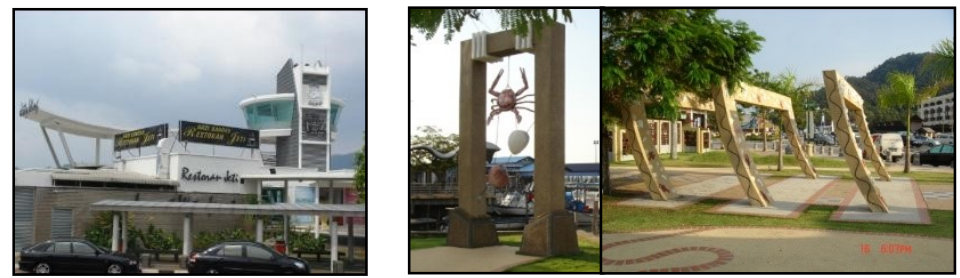

Picture 2: (a) Jetty Wing; (b) Hardscape landscape.

The element of the soft, arch-based landscape, which uses the maritime concept, is also adopted in the surrounding area of the jetty. Picture 2(b) shows the preparation of the landscape element with the water concept, such as the water fountain in the middle part of the jetty entrance, makes the area more beautiful. It provides a positive visual effect and comfort to the visitors. The Jetty Wing is also complete with the Plaza Promenade, which has 2 units of fast food restaurants, 10 units of sea product stalls and 3 units of kiosks known as the Medan Dato' Ishak. The terminal plain has a landscaped area with the maritime concept, which is suitable for relaxing activities. The tourism centre building serves as the key element in terms of the function of the area. The Lumut Development and Management Unit, Lumut Tourism Information Centre, Manjung City Council (MPM) has been established to manage and implement management duties related to tourism in the District of Manjung.

\section{c. Esplanade Wing}

The Esplanade Wing has an area of 18.99 acres with a development cost of RM26 million. This property is privately owned, although the establishment of the International Sailing Club will enable it to diversify the functions of the area and offers another added advantage to the public. This area also plays its role as the entrance to the sailors from within the country and outside of the city of Lumut. This factor indirectly contributes to the advancement of the industry in the city of Lumut. The Esplanade Park is open to the public on the $15^{\text {th }}$ of August, 1996 and to attract the visitors to come to Pangkor Island. Other than its location, which was near the jetty, the beautiful landscape factor also tends to call the visitors' attention. The Manjung City Council provides various facilities at this park. Amongst them are the handicraft centre, food stalls and information centre (see Picture 3). The design of the passenger jetty provided in this area was built based 
Mohd Ismail Isa

Evolution of Waterfront Development in Lumut City, Perak, Malaysia

on the concept of the sea waves, and this is evident on the roof of the pedestrians' pathways. The construction structure used was metal and concrete, and this indirectly will make the maritime design prominent in this area. Featured images in this area have a blend of heritage and modern architecture. Buildings in the jetty area focused more on modern infrastructure by featuring maritime concepts. The administrative centre building in the area focused on the traditional concepts and preservation of heritage features.

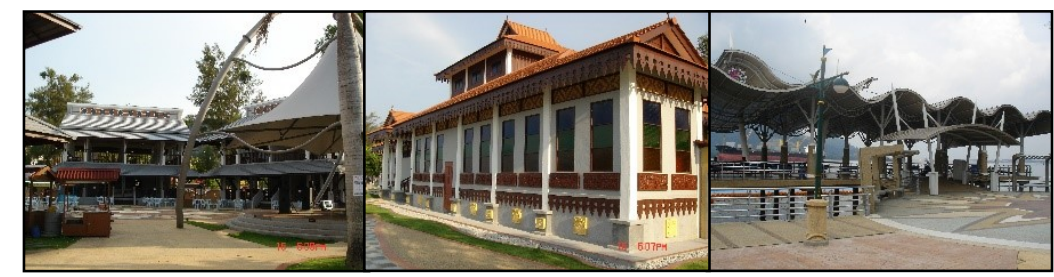

Picture 3: Esplanade Wing.

\section{d. Marina Wing}

The Lumut Waterfront Public Park has an area of 7.4 acres with the development cost reaching RM6 million. It is located in front of the Dinding Strait. The park was officiated on 29 November 2004 or 16 Syawal 1425 H by the D.Y.T.M Crown Prince of Perak, Raja Nazrin Shah Ibni Sultan Azlan Muhibbudin Shah. Facilities available in this park include a restaurant, kiosk, six units of food stalls, the 'Marina Plaza', 'Marina Wall' and a children's playground. Some suggestions include reclaiming the river area up to $\mathrm{Ng}$ Kok Tai Factory, thereby enabling the place to be made extended by 3 acres with a reclamation cost of approximately RM5 million. Marina Wing has a building design that is luxurious in terms of interior design. The reason is that a marina of this type has a function of attracting the rich in this region to transit and conduct their businesses. The architectural concept of the Marina Wing originated from the ship. The combination used in this architecture produces an interesting design (see Picture 4). The use of unique construction materials along the pathways, such as gravel, pebble, granite, cellular or crib paving, terrazzo, sandstone, limestone and slate, as the view by the seashore becomes considerably eye-catching. This condition has attracted people to visit the place to enjoy the comfortable and peaceful ambience of the area. Furthermore, with the provision of the restaurants by the seashore, the turnout of visitors will improve. The combination of activities related to food, drinks and recreational activities served as the common development by the shore. Moreover, the building design appeals to the people. This area was also equipped with recreational and resting places by the seashore, complete with an interesting landscape. The elements of architecture and exclusive detailing in this area should be able to improve the status of an activity, particularly at the 
seashore. The Marina Wing is also surrounded by shaded trees, thereby rendering this area as a peaceful 'forest city'. This area provides a children's playground and sufficient rest area for visitors.

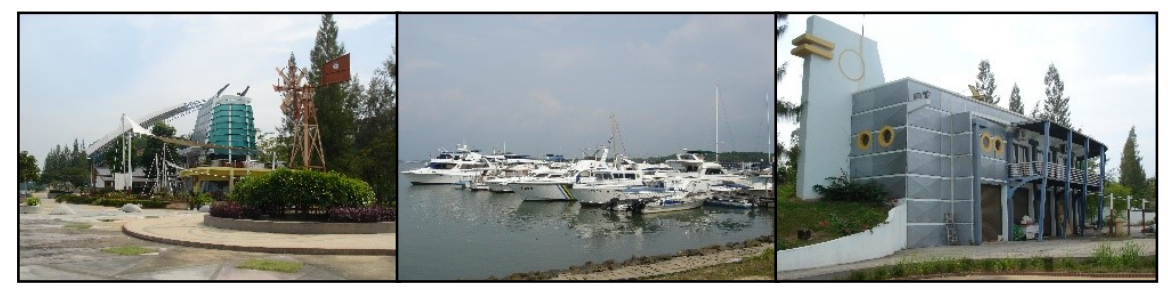

Picture 4: Marina Wing.

\section{DISCUSSION AND CONCLUSION}

Maritime-based development can provide a positive image to visitors on the basis of visual analysis through the observation method. The design adopted in the study area centralised on the marine concept has made it interesting and unique. Nevertheless, some shortcomings in this type of development have been observed. Particularly, the height of the buildings in the study area does not demonstrate consistency, thereby providing strong evidence of a lack of height control implemented on the majority of the buildings. The local authority should embark on judicial supervision before any approval of development is made, thereby ensuring that the image of the city will not be affected negatively. The city design is the outcome of the best collaborative art. Such a design stresses the change of the environment and the idea of the environmental change that will benefit the general public as intended. However, city design is an ongoing process in shaping the image and identity of the city, its surroundings and the community environment. The influence of waterfront development will increase the assets and land around it. For example, when a development area was provided with various facilities, accessibility, comfort, safety and infrastructure, it can attract the arrival of the local community to settle down and live in. The demand and surrounding attractions will indirectly attract investors within and outside the country to invest in and boost its economic development. Land value will also increase, and waterfront development will open additional opportunities for residents to improve their quality of life. Before the development of the waterfront, dealers or traders conducted their business activities on the road shoulders. However, everything changed when development was realised. Businesses were centrally located within the facility and were substantially better than before. This type of development will also enable visitors to easily buy their products. Apart from business activities, development has also created a range of activities in the surrounding waterfront area. For example, buildings and facilities 
Mohd Ismail Isa

Evolution of Waterfront Development in Lumut City, Perak, Malaysia

at the Maritime Wing have provided function spaces as recreational places, where visitors can enjoy their meals. This area is equipped with the shore restaurant, which emphasises the refreshing sea view, making this place crowded and cheerful at night. The peaceful and comfortable feelings towards the sea have further elevated the status of the place. Lumut Jetty Terminal (Jetty Wing) is the transit place of tourists to Pangkor Island. This jetty is an important landmark of the city of Lumut. The design adopts the attributes of a marina, which illustrated a new image which suits the theme. The Jetty Wing is also complete with the plaza promenade, which has 2 units of fast food restaurants, 10 units of sea product stalls and 3 units of kiosks known as the Medan Dato' Ishak. The terminal plain has a landscaped area with the maritime concept, which is suitable for relaxing activities. The Esplanade Wing is a privately owned area, and the establishment of the International Sailing Club will enable this area to diversify its functions and offer another added advantage to the public. Moreover, this area serves as entrance to sailors from within the country and outside of the city of Lumut. This factor indirectly contributes to the advancement of the industry in the city of Lumut. The Marina Wing has a building design that is luxurious in terms of the interior design. The reason is that a marina of this type attracts the rich people in this region to transit and conduct their businesses. The architectural concept of the Marina Wing originated from a ship. The combination of activities in terms of food, drinks and recreational activities serves as the common development by the shore. Moreover, the building design appeals to the people. This area is also equipped with recreational and resting places by the seashore, complete with an interesting landscape.

The data analysis through the questionnaire method indicated that the respondents provided some positive responses to the image and design of the city of Lumut. The feedback of the respondents indicate that they were satisfied with the improvements to the image and infrastructure of the study area. The project cost for the Waterfront Lumut Stretch, which is RM43, 353,090.00, has left such a lasting impact on the direction of the area's current development and that for the future. The measure of MPM in improving the design elements of the city of Lumut has been a fruitful venture. The inventory indicated that the existing shophouse buildings with an interesting facade should be encouraged and maintained. Even the walkway in front of the shops is uniform in terms of height, width and the level of walkway and ceiling. The distance between the streetscape at the walkway is coordinated to create a breathtaking view. However, every element adopted should prioritise the architectural design of the state of Perak. The same principle applies to the housing development in this area. Every design should fulfil the criteria and mirror the culture of Malaysia, particularly the culture of Perak. Amongst the types of housing development introduced are the terrace houses, low-cost flats and medium-cost flats. Moreover, the houses must be constructed to fit the local criteria. 
The study outcome reached the research purpose and objectives. This research should be continued and expanded by studying other related aspects, and the outcomes can be considered points of reference in determining an efficient and effective development for the benefit of every party involved.

\section{ACKNOWLEDGEMENTS}

The authors would like to thank the School of Housing, Building and Planning, Universiti Sains Malaysia and the Ministry of Education under the Fundamental Research Grant Scheme (FRGS) 203/PPBGN/6711668 for providing financial support to this research.

\section{REFERENCES}

Dong, L. (2004). Waterfront Development: A case of Dalian. Unpublished master's thesis, University of Waterloo, Canada.

Jabatan Perancangan Bandar dan Desa. (2010). Rancangan Struktur Negeri Perak 2015 2020. Perak Darul Ridzuan: Perak Goverment Printing Office.

Malaysia. Kementerian Perumahan dan Kerajaan Tempatan. (2003). Garis Panduan Dan Piawaian Perancangan Reka Bentuk Imej Bandar. Kuala Lumpur: Jabatan Perancangan Bandar dan Desa.

Manjung City Council. (2007). Pelan Jaluran Lumut Waterfront 2007 - 2020. Perak: Manjung City Council Printing Office.

Morena, M. (2011). Morphological, Technological and Functional characteristics of infrastructures as a vital sector for the competitiveness of a country system, Milano, pp. 195.

Pelan Induk Landskap 2005-2015. Perak Darul Ridzuan: Majlis Perbandaran Manjung.

Wrenn, D. M., Casazza, J. A., \& Smart, J. E. (1983). Urban waterfront development. Washington: Urban Land Institute.

Yasin, A. B., Bond, S., \& Mc Donagh, J. (2012). Principles for sustainable riverfront development for Malaysia. Journal of Techno-Social, 4, 21-36.

Yasin, A. B., Even, C., \& McDonagh, J. (2010). An Evolution of waterfront development in Malaysia. Paper presented at Pacific Rim Real Estate Society Conference Wellington.

Received: January 2020. Accepted: $14^{\text {th }}$ May 2020 